Meta

Journal des traducteurs

Translators' Journal

\title{
Investigating Cultural Competence in English-Arabic Translator Training Programs
}

\section{Showqi Bahumaid}

Volume 55, numéro 3, septembre 2010

URI : https://id.erudit.org/iderudit/045078ar

DOI : https://doi.org/10.7202/045078ar

Aller au sommaire du numéro

Éditeur(s)

Les Presses de l'Université de Montréal

ISSN

0026-0452 (imprimé)

1492-1421 (numérique)

Découvrir la revue

Citer cet article

Bahumaid, S. (2010). Investigating Cultural Competence in English-Arabic Translator Training Programs. Meta, 55(3), 569-588.

https://doi.org/10.7202/045078ar

\section{Résumé de l'article}

Le présent article fait état d'une étude empirique examinant la compétence traductionnelle anglais-arabe atteinte par les étudiants en traduction inscrits aux cycles supérieurs de l'Université américaine de Sharjah et de l'Université de Sharjah, aux Émirats arabes unis. Plus spécifiquement, la traduction anglais-arabe d'un échantillon soigneusement choisi de quinze expressions culturellement spécifiques, contextualisées dans des phrases, a été examinée. L'étude s'est également penchée sur la conscience qu'ont les étudiants des procédés de traduction utilisés. Les performances des sujets quant à la traduction d'expressions à contenu culturel dans les deux langues se sont montrées assez faibles. Les principales erreurs repérées sont les erreurs de sens, les sous-traductions et les omissions. Il semble que les erreurs soient en grande partie dues à la méconnaissance de la culture anglaise par les sujets, à leur incompréhension de la signification de la traduction et à un usage défectueux des dictionnaires. De plus, les sujets se sont révélés méconnaître les procédés de traduction des expressions culturellement spécifiques. L'étude conclut par des suggestions visant à développer la compétence culturelle chez les étudiants des programmes de formation en traduction anglais-arabe aux cycles supérieurs.
Ce document est protégé par la loi sur le droit d'auteur. L'utilisation des services d’Érudit (y compris la reproduction) est assujettie à sa politique d'utilisation que vous pouvez consulter en ligne.

https://apropos.erudit.org/fr/usagers/politique-dutilisation/ 


\title{
ÉTUDES ET PROSPECTIVES
}

\section{Investigating Cultural Competence in English-Arabic Translator Training Programs}

\author{
SHOWQI BAHUMAID \\ University of Sharjah, Sharjah, United Arab Emirates \\ sbahumaid@sharjah.ac.ae
}

\section{RÉSUMÉ}

Le présent article fait état d'une étude empirique examinant la compétence traductionnelle anglais-arabe atteinte par les étudiants en traduction inscrits aux cycles supérieurs de I'Université américaine de Sharjah et de l'Université de Sharjah, aux Émirats arabes unis. Plus spécifiquement, la traduction anglais-arabe d'un échantillon soigneusement choisi de quinze expressions culturellement spécifiques, contextualisées dans des phrases, a été examinée. L'étude s'est également penchée sur la conscience qu'ont les étudiants des procédés de traduction utilisés. Les performances des sujets quant à la traduction d'expressions à contenu culturel dans les deux langues se sont montrées assez faibles. Les principales erreurs repérées sont les erreurs de sens, les sous-traductions et les omissions. II semble que les erreurs soient en grande partie dues à la méconnaissance de la culture anglaise par les sujets, à leur incompréhension de la signification de la traduction et à un usage défectueux des dictionnaires. De plus, les sujets se sont révélés méconnaître les procédés de traduction des expressions culturellement spécifiques. L'étude conclut par des suggestions visant à développer la compétence culturelle chez les étudiants des programmes de formation en traduction anglais-arabe aux cycles supérieurs.

\section{ABSTRACT}

This empirical study investigates the level of translation competence in English-Arabic translation among postgraduate translator trainees in the American University of Sharjah and the University of Sharjah in the United Arab Emirates. It specifically examines the trainees' competence in rendering from English into Arabic a carefully selected sample of fifteen culture-specific expressions used in contextualized sentences, as well as the trainees' awareness of the translation procedures employed in their renditions. The results have revealed the informants' rather low performance in the renditions of culturebound expressions from English into Arabic; their major types of errors involved incorrect meaning, under-translation and omission. The errors have been mainly attributed to the informants' inadequate knowledge of English culture, their lack of awareness of the significance of the translation brief while translating, and their inappropriate use of dictionaries. Further, the informants' improper knowledge of the translation procedures employed in rendering culture-specific expressions has been evidenced. The paper ends by offering some suggestions for developing cultural competence in postgraduate English-Arabic translator training programmes.

\section{MOTS-CLÉS/KEYWORDS}

culture, compétence en traduction, compétence culturelle, terme culturellement spécifique, enseignement de la traduction

culture, translation competence, cultural competence, culture-bound terms, translation teaching 


\section{Introduction}

The early 1980s witnessed the emergence, in translation studies, of a culturally oriented approach to translation. This approach embraces the view that every text is anchored in a specific culture, and that conventions of text production and reception vary from culture to culture. The term culture is an all-embracing term that covers not only material aspects but also conceptual, philosophical, political, religious and artistic facets in addition to social customs and traditions. As Nida (1994: 157) puts it, culture refers to "the total beliefs and practices of a society." Translation, in this new outlook, is firmly grounded in its cultural context and is viewed primarily as a cross-cultural event (Snell-Hornby 1988: 46). Accordingly, the translator's role has widened: translators are now looked upon as mediators between two cultures, not merely two languages (Hatim and Mason 1990: 223). To perform the role of intercultural mediation, the translator, it is argued, should be well versed in the cultures of both source and target languages. Indeed, some scholars (Vermeer 1989/2000) have insisted that the translator should be bicultural, if not multicultural. A fresh perspective focusing on the cultural aspects of translation emerged. This trend has gained a great impetus over the past few decades. Scores of studies investigating intercultural translation issues have appeared in various journals and have been debated in several translation conferences and seminars. The English-Arabic translation studies movement was no exception.

\section{Culture-oriented translation studies (English-Arabic): an overview}

Viewed from a cultural perspective, three distinct types of English-Arabic translation studies may be identified. The first type of studies have examined culture-bound problems within the wider context of the difficulties encountered in translating various texts from English into Arabic and vice versa (Shunnaq 1988). In other words, culture is seen here merely as one of several sources of the problems faced by translators in their arduous task of tackling morphological, syntactic, lexical, textual and discoursal features of different source-language texts. The second type of EnglishArabic translation studies particularly deal with culture-bound problems in specific texts. In this respect, several studies (Aziz 1985; 1999; Farghal and Borini 1998; Abdel-Hafez 2004) have investigated culture-bound problems in literary texts while others (Barkho 1987; Shunnaq 2000) have highlighted such problems in political texts. Culture-specific terms and expressions in Islamic texts have been addressed in a few other studies (Faiq 1998; Homeidi 2004). The third type of culturally oriented studies takes a different outlook as it seeks to highlight cross-cultural links between English and Arabic (Ghazala 2002).

\section{Cultural Competence in Translation}

Cultural competence, as used in this paper, involves the following six main elements that may be grouped into three categories:

1) Encyclopedic knowledge of the source and target cultures:

a) knowledge about historical, geographical, political, economic, social, cultural, educational, legal, administrative, etc.;

b) aspects in the countries of both source and target languages. 
2) Cultural awareness:

a) awareness of the relation between language and culture with all its ramifications and implications for the translator;

b) awareness of cultural similarities and perhaps more importantly, differences between the cultures of both source and target languages.

3) Specific translation skills:

a) expertise in the translation strategies that should be employed in handling culture-laden texts. A translation strategy (Delisle, Lee-Jahnke et al. 1999) - or translation method, as some scholars (Newmark 1988) call it - refers to a coherent plan of action adopted by translators in translating a given text;

b) acquisition of adequate skills in the rendition of culture-bound terms that occur in various genres and text types. Culture-bound terms (CBTs), which are used in this paper interchangeably with culture-specific terms, may be defined, following Harvey (2003: 2), as "concepts, institutions and personnel, which are specific to the SL culture";

c) expertise in the translation procedures that are used in rendering CBTs. Translation procedures differ from translation methods in that the former relate to whole texts while the latter are used for sentences and the smaller units of language (Newmark 1988).

\section{Studying cultural competence}

\subsection{Rationale}

Cultural competence, the concern of this study, is considered one of the main subcompetencies of translation. As explained above, the emphasis laid in recent literature on the role of the translator as a cultural mediator has even enhanced the significance of cultural competence for both theoretical investigation and practical concerns related to its integration and development in translator training programmes. The present study may be further justified on account of the fact that no attempt has been so far made, to the knowledge of the present writer, to investigate the extent to which English-Arabic translator programmes in Arab universities have succeeded in developing cultural competence in their trainees.

\subsection{Aim}

The aim of this study is to assess the level of cultural competence in English-Arabic translation among postgraduate students who are pursuing their studies in translator-training programmes in Arab universities. It focuses on three aspects of cultural competence in translation, namely, knowledge of some aspects of both source and target cultures, acquisition of adequate skills in the rendition of culture-specific terms, and awareness of the translation procedures used in the rendition of those terms. For the purposes of the study, a 'test of cultural competence in translation' was designed and administered to students enrolled in two postgraduate programs in the United Arab Emirates:

1) the Master Program in English-Arabic Translation (MPT) at the University of Sharjah (UoS), and;

2) the M.A. program in English/Arabic/English Translation and Interpreting (MATI) at the American University of Sharjah (AUS). 
Selection of these two Master programmes was made on the grounds that:

a) they are the only postgraduate programmes in English-Arabic Translation offered in the United Arab Emirates that were accessible for the study;

b) they have a comparable structure: AUS offers 36 credits, 27 of which are compulsory including a research thesis and 9 elective credits, while UoS offers 34 credits, 22 of which are compulsory including a dissertation and 12 elective credits;

c) they offer similar courses in the two main areas of translation and linguistics, and;

d) they offer, a 3-credit elective course on issues of culture in translation, titled the cultural trend in translation studies at UoS, and intercultural communication at AUS (see AUS 2006 and UoS 2006).

Results of the test will be then analyzed and plausible explanations for the performance of the informants in the test will be sought. Finally, specific recommendations and suggestions aimed at developing cultural competence in the translation trainees in those institutions will be made.

\subsection{Research Instrument: Test of Cultural Competence in Translation}

As indicated in Section 4.2. above, a Test of Cultural Competence in Translation (TCCT) was used as a research instrument. The TCCT included thirteen contextualized sentences drawn from a hypothetical text about British life and culture. It was assumed that the text was prepared by the British Council for the purpose of providing Arab students who wish to pursue their graduate studies in British universities with some basic information about Britain and the British way of life. The subjects were asked to give the most appropriate Arabic renditions of fifteen English culturespecific words and phrases underlined in those text segments.

The CBTs selected by the researcher for inclusion in the TCCT presented translation problems. We adopted Nord's (1991: 150) definition of translation problems as "those points, which prove a challenge for all translators in a particular language combination." The CBTs were drawn from several genres:

a) literary (e.g., as beautiful as a lark);

b) religious (e.g., Merry Christmas, Lent);

c) political (e.g., Speaker of the House of Commons, the poll tax), and;

d) social (e.g., go trick-or-treating).

They covered various areas of human life such as food and drink (e.g., cream tea) and sport (e.g., soccer hooligans). From the linguistic perspective, the culture-specific expressions included in the TCCT belong to different categories:

a) metaphors (e.g., to stir one's stumps);

b) similes (e.g., as beautiful as a lark), and;

c) proverbs (e.g., English love me, love my dog).

In addition, the CBTs tested present varying levels of difficulty of rendition. They include fairly simple terms (the British Council), others which may be considered of average difficulty (Speaker of the House of Commons, Madame Tussauds) as well as some expressions that are rather challenging (to stir one's stumps). It should be further noted that some of the CBTs involved in the test have been mentioned in various English-Arabic translation books, which are available in the libraries of some Arab 
universities as well as in several bookshops in the Arab region (e.g., Speaker of the House of Commons, cream tea, and Merry Christmas - Baker 1992: 21, 33; as beautiful as a lark, love me, love my dog, and to stir one's stumps - Ghazala 2006: 196, 142, 151; The British Council - Kharma 1997: 27; hooliganism - Farghal and Shunnaq 1999: 28). Three other terms or expressions, i.e., Lent, punk, and trick or treat, were drawn from The World of English (Farrell, Rossi, et al. 2004: 13, 18, 26), a course book on British life and culture. The researcher added several other cultural terms, i.e., $a$ three-course meal; Madam Taussaud; Lager louts, on the basis of his knowledge of the Arab (native) culture as well as his fairly good knowledge of the British culture as he pursued his postgraduate studies in the universities of Wales, Leeds, and Exeter for about six years.

In addition to rendering the thirty CBTs included in the test, the subjects were asked to mention the translation procedures they used in rendering five of those terms - marked in bold type in the test (Appendix 1). The translation procedures involved in the rendition of those ten CBTs were as follows:

a) Cultural equivalence, which means replacing a cultural term in the SL with a TL one (Newmark 1988: 83). This procedure is used, in the TCCT, in the rendition of the culture-bound English expression love me, love my dog into its Arabic I و أحبها وتحبني، ويحب ناقتها بعيري love her and she loves me and my camel loves her she-camel);

b) Calque (loan translation or Newmark's (1988: 84) through-translation), e.g., rendering the culture-specific English term poll tax into Arabic ضريبة الاقتر اع (poll tax);

c) Descriptive equivalent, that is, explaining the meaning of the original CBT in several TL words (Newmark 1988: 83), e.g., rendering English Merry Christmas into Arabic ليكن احتفالك بعيد ميلاد المسيح سعيداً (lit.: Let your celebration of the birth of Jesus Christ be happy);

d) Paraphrase (gloss, or note), i.e., providing an explanation of the CBT, which, as Newmark (1988: 91) points out, is often much more detailed than that of a descriptive equivalent. This procedure was used in, for example, the rendition of English a threeوجبة عثاء تتكون من ثلاثة أجز اء تبدأ بتناول طبق "فاتح للثهية" كالمرق

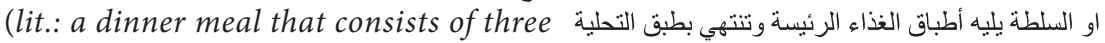
parts starting with an appetizer such as soup or salad followed by the main dish and ending with dessert);

e) Transcription or borrowing (or Catford's (1965) transference), which involves reproducing or transliterating the SL term when no suitable equivalent for it exists in the TL. The latter procedure was combined with paraphrase in rendering, for example, the culture-specific English expression punk into Arabic pointed out that the translation procedures selected for our test represent some of the most commonly used procedures in translating culture-specific expressions.

Prior to the test, the writer explained the aim of the test to the subjects noting that they do not have to write their names and emphasizing that its results will be used for research purposes only. The subjects were asked to write the answers in the spaces provided on the test paper and were allowed to use dictionaries and any other reference works. One of the subjects inquired if she could search the Internet while taking the test and the researcher permitted her and all other subjects to do so if they wished. No time limit was set for the test.

To ascertain the validity of the TCCT, it was given, in a draft form, to two translation specialists who have taught translation courses to both undergraduate and 
postgraduate students and have published several translations of acknowledged worth. Both confirmed that the test was valid and suggested no changes, additions or omissions.

\subsection{Informants}

A total of 10 students kindly accepted to take the TCCT. Of these, five are registered in the Masters Program in English-Arabic Translation at the University of Sharjah in the academic year 2006-2007 and the same number of students is enrolled in the M.A. program in English/Arabic/English Translation and Interpreting at the American University of Sharjah. Most of the informants were in their second semester in their M.A. translation studies while a few were in their third. The native language of the informants was Arabic. All the informants, except one, were female.

\subsection{Limitations of the study}

This study may have been constrained by three factors. First, the study was confined to only three components of cultural competence in translation, as mentioned in Section 5.2. Obviously, not all the various elements involved in cultural competence in translation could, for space limitation, be investigated in a single study; therefore selection of some of those elements had to be made to the exclusion of others. Secondly, the number of M.A. translation students who took the TCCT was rather small, namely, ten. This could be considered an acceptable number on account of the fact that the student enrollment in such programs in Arab universities is generally limited. Thirdly, the study was constrained by the rather small size of culture-specific terms (totaled 15) included in the TCCT. However, those terms, as shown in Section 5.3. above, have been carefully selected to ensure that they are drawn from various registers, belong to different linguistic domains and present varying degrees of difficulty for rendering from English into Arabic. It should be pointed out that the researcher makes no claims as to the generalizability of the findings of the study to other contexts. Having said that, one may not completely rule out the possibility that the results arrived at in this study might apply to similar postgraduate programmes elsewhere.

\section{Results and discussion}

Although the informants were allowed to use dictionaries and any other reference works, as well as to search the Internet while taking the TCCT, and despite the fact that no time limit was set for the test, their overall performance in the test was entirely unsatisfactory.

\subsection{The informants' performance in the Arabic renditions of English CBTs}

The informants exhibited a rather low performance in their Arabic renditions of the English CBTs tested. Table 1 presents the informants' overall scores in this part of the test. 
TABLE 1

Overall scores of the informants in English-Arabic renditions

\begin{tabular}{|c|c|c|c|c|}
\hline Informant & $\begin{array}{c}\text { Number of } \\
\text { Correct } \\
\text { Renditions }\end{array}$ & $\begin{array}{c}\text { Number of } \\
\text { Incorrect } \\
\text { Renditions }\end{array}$ & $\begin{array}{c}\text { Number of Test } \\
\text { Items Not } \\
\text { Attempted }\end{array}$ & $\begin{array}{c}\text { Correct } \\
\text { Renditions (\%) }\end{array}$ \\
\hline 1 & 1 & 11 & 3 & 6.66 \\
\hline 2 & 4 & 6 & 5 & 26.66 \\
\hline 3 & 2 & 10 & 3 & 13.33 \\
\hline 4 & 4 & 11 & 0 & 26.66 \\
\hline 5 & 2 & 12 & 1 & 13.33 \\
\hline 6 & 5 & 9 & 1 & 33.33 \\
\hline 7 & 1 & 11 & 3 & 6.66 \\
\hline 8 & 4 & 9 & 2 & 26.66 \\
\hline 9 & 2 & 9 & 4 & 13.33 \\
\hline 10 & 1 & 14 & 0 & 6.66 \\
\hline
\end{tabular}

As shown on the table, all the informants obtained rather low scores in this part of the test. The highest score was $33 \%$, obtained by one informant only, whereas the other scores were even lower: $27 \%$ (three informants), $13 \%$ (three informants), and $7 \%$ (three informants). Meanwhile, the informants as a group provided a total of 26 correct renditions (17\%), while the remaining items were either incorrect (102 items - 68\%) or left blank (22 items - 15\%). Besides, a comparison of the performance of the group of informants registered in the MPT at UoS (i.e., Informants 1-5) and that enrolled in the MATI at AUS (i.e., Informants 6-10) in this part of the test revealed that their overall scores were very close, with the former providing 13 correct responses, 50 incorrect responses and 12 items left blank, whereas the latter scored 13 correct responses, 52 incorrect ones and 10 items not attempted.

\subsubsection{Correct Arabic renditions of the English CBTs}

In our discussion of the informants' correct and incorrect renditions, we shall refer to the answer key of the test (See Appendix 2). Given the fact that no single perfect rendition exists for a text, the researcher considered as correct any rendition attempted by an informant, which might diverge from his version but is still contextually acceptable. This was applied to several renditions given by some informants, as shown on table 2 below:

TABLE 2

The informants' correct Arabic renditions of English CBTs

\begin{tabular}{|c|c|c|}
\hline Serial Number & English CBTs & Informants' Renditions \\
\hline 1 & The British Council & $\begin{array}{l}\text { المجلس الثقافي البريطاني } \\
\text { (lit.: the British cultural council) }\end{array}$ \\
\hline 2 & A three-course dinner & 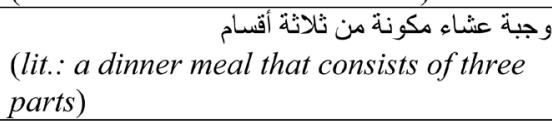 \\
\hline 3 & Madame Tussauds & (lit.: wax museum) \\
\hline
\end{tabular}




\begin{tabular}{|c|c|c|}
\hline 4 & Trick-or-treat & لملوى أو خدعة \\
\hline 5 & Poll tax & 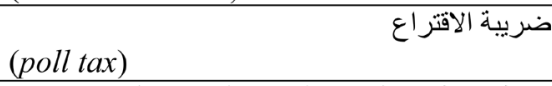 \\
\hline 6 & Cream tea & $\begin{array}{l}\text { وجبة خفيفة من الخبز و الزبدة والمربى و الثاي } \\
\text { (lit.: a light meal of bread, butter, jam } \\
\text { and tea) }\end{array}$ \\
\hline 7 & Love me, love my dog & $\begin{array}{l}\text { لاجل عين تكرم مرج عيون } \\
\text { (lit.: for the sake of one eye, a host of eyes } \\
\text { are honored) }\end{array}$ \\
\hline
\end{tabular}

It should be noted that although the Arabic renditions opted for by the informants for the English terms 1, 2, 3, 4, and 5 above might be semantically and contextually appropriate, they do not meet the requirements of the intended readership as specified in the translation brief. In other words, the target readers of those renditions, i.e., Arab students who are going to pursue their postgraduate studies in Britain, are assumed to have little knowledge of the British culture and would therefore find the informants' renditions rather uninformative. Hence, it would be necessary to add some explanation or gloss to each of those renditions along the lines suggested by the researcher (Appendix 2). As for the Arabic rendition given above for English cream tea, it appears to have conveyed the basic meaning of the term. However, the rendition contains a few imprecise details about this light meal, which is defined in the COBUILD Dictionary of English (Sinclair 1987: 584) as "an afternoon meal consisting of tea to drink and scones with jam and clotted cream to eat." Finally, the Arabic equivalent provided by the informants for the English proverbial expression love me, love my dog, is actually used in some local dialects of Arabic. It would not, however, be understood by speakers of other dialects. It is for this reason that the following line of traditional Arabic verse, which is proposed by several writers (Ghazala 2006:142) as equivalent to the English CBT discussed, might be considered a better option: و أحبها وتحبني ويحب ناقتها بعيري (lit.: and I love her and she loves me, and my camel loves her she-camel).

\subsubsection{Incorrect Arabic renditions of the English CBTs}

As indicated in section 5.1. above, most of the renditions attempted by the informants (68\%) were incorrect. These renditions may be divided into five categories depending on the type of translation error made by the informants. This section discusses these errors and offers some possible explanations of their causes.

\subsubsection{Errors of 'incorrect meaning'}

It was observed that in their renditions of most of the English CBTS tested, many informants failed to provide the correct meanings of their Arabic counterparts. In fact, this translation error turned out to be the most common error made by the informants. A list of the informants' Arabic renditions involving the translation error of incorrect meaning is given on table 3 below. 
TABLE 3

The informants' translation errors of 'incorrect meaning' (English-Arabic)

\begin{tabular}{|c|c|}
\hline English CBTs & Informants' Incorrect Arabic Renditions \\
\hline The British Council & 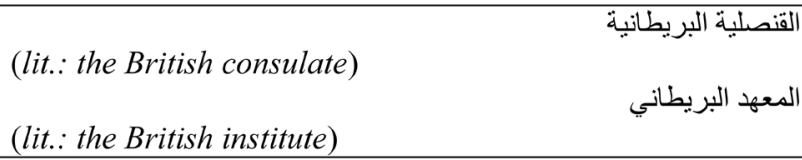 \\
\hline $\begin{array}{l}\text { Speaker of the House of } \\
\text { Commons }\end{array}$ & $\begin{array}{l}\text { (lit.: a spokesperson of the House of Commons) } \\
\text { (lit.: the spokesperson of the Deputies Council) } \\
\text { (lit.: speaker of the People's Assembly) }\end{array}$ \\
\hline A three-course dinner & $\begin{array}{ll}\text { (lit.: a three-part lunch) } & \text { غناء من ثلاثة أقنسام لثلاثة أنثخاص } \\
\text { (lit.: dinner for three persons) } & \end{array}$ \\
\hline Soccer hooligans & جماهير الكرة الغوغائيون \\
\hline A punk & 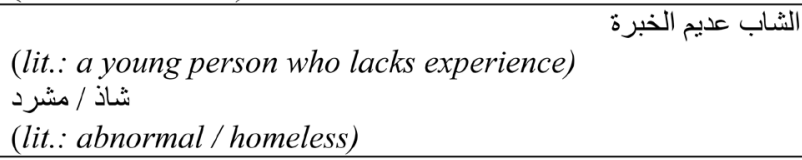 \\
\hline Love me, love my dog & (lit.: love me and my dog) \\
\hline To stir one's stumps & $\begin{array}{l}\text { (lit.: to disturb a person) } \\
\text { (lit.: to arouse his suspicions) }\end{array}$ \\
\hline Madame Tussauds & (madam Tosadis) \\
\hline Go trick-or-treating & (lit.: they go to ask for the sweets of Halloween) \\
\hline Lager louts & $\begin{array}{l}\text { (lit.: a foolish person) } \\
\text { (lit.: idiots) }\end{array}$ \\
\hline The poll tax & $\begin{array}{l}\text { (lit.: taxes law) } \\
\text { (lit.: tax collection) } \\
\text { (lit.: heads tax) } \\
\text { (lit.: head tax) }\end{array}$ \\
\hline Cream tea & (lit.: tea with cream / milk) \\
\hline Lent & \\
\hline
\end{tabular}


A close examination of the informants' errors involving incorrect meanings of the English CBTs above reveals that such errors may be attributed to several causes. The most important of these is the informants' lack of knowledge of the source language (English) culture-specific terms. This is quite evident in the informants' renditions of, for example, the terms Speaker (of the House of Commons) المتحهن (Speaker) or يضايق (idiots), to stir one's stumps as حمقى ناطق رسمي (Spokesperson), Lager louts as شخصاً يثير شكوكه (to disturb a person) or arouse his suspicions).

A further related cause of the informants' erroneous renditions is their lack of awareness of the differences between the source (English) and target (Arab) cultures. A case in point is the informants' rendition of English dinner as غداء (lunch) rather than عثناء (dinner). This may be ascribed to the fact that lunch is the main meal of the day in most Arab countries while in Britain the main meal is dinner. Similarly, interference of the target (Arab) culture might explain the informants' renditions of the English culture-bound term House of Common as مجلس النواب (Deputies Council) and مجلس الثُعب (People's Assembly), which are the names of parliaments in their own countries. A more striking case of interference of the target (Arab) culture is the rendition, by one of the informants, of English poll tax as الجزية (head tax). This culture-bound Arabic term was used in the early Islamic era to refer to the head tax paid by non-Muslim citizens to the Islamic state which is responsible for their protection (Saleh 2001: 49). The informant who provided this rendition seemed to have fallen into the trap of copying that word from a dictionary (i.e., Atlas Encyclopedic Dictionary 2002: 976) with disregard to the context in which the source (English) term was used.

Outright copying from dictionaries without making any attempt to modify the copied material so that it suits the context and purpose of the translation is perhaps the cause of a few other incorrect renditions made by the informants. These include the renditions of English hooligans as غو غائيين (mobs - Atlas Encyclopedic Dictionary: English-Arabic 2002: 604), punk as̈ة شاب عديم الخبر (a young person who lacks ضريبة الرؤوس (heads tax - Baalbaki 2000: 705). It is worth mentioning that through our personal communication with some translator trainers in several Arab institutions, we often hear the complaint that during the process of translation, many translation trainees in such institutions tend to rush to look up the meanings of unfamiliar source-language words in bilingual (English-Arabic / Arabic-English) dictionaries and copy the meanings of the words with disregard to the contexts in which those words are used. In doing this, the translator trainees seem to ignore the advice of their translation instructors who continuously caution them against the injudicious use of dictionaries and frequently remind them that such dictionaries may become a trap for the translator if not used skillfully. We believe that incorporating the appropriate use of dictionaries into translation classes in those institutions and providing translator trainees with frequent opportunities for the proper use of dictionaries might help in tackling this chronic problem.

A further possible cause of the incorrect renditions indicated in table 4 above is the inadequate proficiency in English of some of the informants as evidenced in the renditions of English The British Council as المعهد البريطانى (the British institute) or as القنصلية البريطانية (the British consulate) and three-course dinner as عثاء لثناثة أشخاص (dinner for three persons). 
A few more of the informants' incorrect renditions clearly indicate their lack of awareness of the significance of the translation brief. This has resulted in giving renditions that do not take the purpose, context and the intended readership of the target text into consideration. For example, the literal rendition of English love me, love my dog as حبني وكلبي (love me and my dog) would in fact evoke rather unpleasant feelings among its readers since a dog often has negative connotations in the Arab culture. A similar, but less serious, error is the rendition of English go trick-or-treating as يذهبون لطلب حلوى الهالوين (go to ask for the sweets of Halloween), which would not be understood by its intended readers simply because the term Halloween presents a cultural void (Shuttleworth and Cowie 1997: 196), as it does not exist in the Arab culture.

To conclude, a number of factors have led the informants to provide incorrect Arabic meanings of the English CBTs tested. These include the informants' rather poor knowledge of the source language (English) culture-specific terms, their lack of awareness of the differences between the source and target cultures, inadequate proficiency in English, improper use of dictionaries, and the failure to recognize the significance of the translation brief while translating.

\subsubsection{Errors of under-translation}

The error of under-translation may be defined as an error where the translator omits in the target text any compensation, amplifications or explicitations required in order to obtain an idiomatic translation that conforms to the presumed sense of the source text (Delisle, Lee-Jahnke, et al. 1999: 197). This error has been made by the informants in their Arabic renditions of some English CBTs, as indicated in table 4 below.

TABLE 4

The informants' errors of 'under-translation' (English-Arabic)

\begin{tabular}{|l|l|}
\hline \multicolumn{1}{|c|}{ English CBTs } & \multicolumn{1}{|c|}{ Informants' Incorrect Arabic Renditions } \\
\hline The British Council & (lit.: the British Council) \\
\hline A punk & (lit.: a young music player) \\
\hline Madame Tussauds & (lit.: Madam Tosaad museum) \\
\hline Cream tea & (lit.: cake and tea) \\
\hline Lent & (lit.: period of Christian fasting) \\
& (lit.: period of religious fasting) \\
\hline
\end{tabular}

A careful study of the Arabic renditions listed on this table clearly shows that they convey only a minimal portion of the meanings of the English culture-bound terms and leave much to be guessed at by the target readers. For example, the literal rendition of The British Council as Arabic المجلس البربطانس (The British Council) is rather ambiguous and would certainly be met with raised eyebrows by its intended Arab readers who would be wondering about which British institution is intended 
in such a rendition. The same argument may be made regarding the remaining Arabic renditions mentioned in table 5 above. Indeed, such renditions would be totally uninformative to the target (Arab) readership. It is, therefore, essential that translator trainees should be made aware of the need to provide detailed explanations or glosses for such terms. For example, the English CBT The British Council, may be rendered along the lines suggested by Kharma (1997: 27) as follows:

(1)

$$
\text { المركز الثقافي البريطاني وهو مؤسسة تسعى الى نشر اللغة الانجليزية وثقافتها في ما وراء البحار }
$$

(lit.: The British Cultural Center, which is an institution that seeks to spread English language and culture overseas.)

Glosses for the rendition of English CBTs a punk and Lent into Arabic have been also proposed by the present writer (Appendix 2).

Errors of under-translation, like the ones noted above, indicate in particular the informants' failure to recognize the significance of taking the translation brief into account while rendering CBTs, a problem noted in our earlier discussion of some semantic errors made by the informants (section 5.1.2.1.).

\subsubsection{Errors of omission}

In making errors of omission, the translator fails to render a necessary element of information from the source text in the target text (Delisle, Lee-Jahnke et al. 1999: 165). Table 5 below provides a list of renditions involving the error of 'omission' made by the informants in the English-Arabic part of the test.

TABLE 5

The informants' translation error of omission

\begin{tabular}{|c|c|}
\hline English CBTs & Informants' Incorrect Renditions \\
\hline As beautiful as a lark & 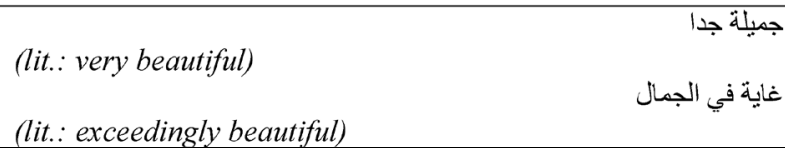 \\
\hline Go trick-or-treating & (lit.: go to ask for sweets) \\
\hline Lager louts & (lit:: the drunken) \\
\hline Merry Christmas & $\begin{array}{l}\text { تهنئة بحلول عيد الميلاد } \\
\text { (lit.: congratulation on the occasion of the birthday) } \\
\text { (lit.: glorious birthday) }\end{array}$ \\
\hline The poll tax & (lit.: $\operatorname{tax})$ \\
\hline
\end{tabular}

Before discussing the informants' renditions of the English CBTs in this table, we should point out that consulting such commonly used English-Arabic dictionaries as Al-Mawrid English-Arabic Dictionary while rendering those terms would be of little help since all those five expressions, with the exception of the poll tax, are simply non-existent in those dictionaries. Hence, the informants appear to have made their own Arabic renditions in which a basic component of each term is 
omitted. Reasons for such omission seem to vary. In their renditions of the English simile as beautiful as a lark, the informants left out the essential word a lark, producing the rather inappropriate Arabic expressions جميلة جداً (very beautiful) and في غاية الجمال (exceedingly beautiful). These two renditions also indicate the informants' failure to recognize that as beautiful as a lark which describes a person's singing voice is a culture-bound simile. Hence, this simile would be best rendered, Sال ع ندل يب جم يل (as beautiful as a nightingale). Meanwhile, failure to take the intended reader of the target text into consideration might explain the informants' omission of the key expressions Christmas (in Merry Christmas) and poll (in the poll tax) thus carelessly rendering these two CBTs as تهنئة بحلول عيد الميلاد (congratulation on the occasion of the birthday) and ضريبة (tax) respectively. The same explanation might be given for the omission, by the informants, of some necessary elements of information in their Arabic renditions of the two English culture-specific expressions Lager louts as (go to ask for sweets). A more adequate rendition of each of these two English CBTs has been proposed by the present researcher (Appendix 2).

\subsubsection{Nonsense errors}

Nonsense errors involve, as Delisle, Lee-Jahnke et al. (1999: 163) state, misinterpreting the meaning of a word in the source text in such a manner that it leads to producing an illogical formulation in the target text. This type of translation error has been noticed in the informants' Arabic renditions of five of the English CBTs, which are indicated in the following table.

TABLE 6

The informants' translation error of nonsense

\begin{tabular}{|c|c|}
\hline English CBTs & Informants' Incorrect Renditions \\
\hline $\begin{array}{l}\text { Speaker of the House of } \\
\text { Commons }\end{array}$ & (lit.: spokesperson of the public house) الدنحدث باسم البيت العام \\
\hline A three-course dinner & (lit.: a dinner that consists of three meals) غداء مكون من ثلاث وجبات \\
\hline A punk & (lit.: a punk person) \\
\hline Lager louts & (lit.: very loud noise) \\
\hline The poll tax & (lit.: the tax of poll) \\
\hline
\end{tabular}

Nonsense errors of the type listed in this table are undoubtedly considered the most serious of the translation errors since they violate one of the basic principles of translation, namely, that it should render the correct contextual meanings of the words of the source text. However, these errors have been made by only a few of the informants in their rendering of an extremely small number of the English CBTs. 


\subsection{The informants' awareness of the translation procedures used in rendering CBTs}

In our assessment of the informants' awareness of the translation procedures often used in rendering CBTs, we asked the informants to indicate the types of translation procedures that they used in their renditions of five of the CBTs included in the test (Appendix 1). Table 7 presents the results of the informants in the five test items on translation procedures in the test.

TABLE 7

The informants' scores in the test items on translation procedures

\begin{tabular}{|c|c|c|c|c|c|}
\hline Informant & $\begin{array}{c}\text { Translation } \\
\text { Procedure 1 }\end{array}$ & $\begin{array}{c}\text { Translation } \\
\text { Procedure 2 }\end{array}$ & $\begin{array}{c}\text { Translation } \\
\text { Procedure 3 }\end{array}$ & $\begin{array}{c}\text { Translation } \\
\text { Procedure 4 }\end{array}$ & $\begin{array}{c}\text { Translation } \\
\text { Procedure 5 }\end{array}$ \\
\hline 1 & $\mathrm{~N}$ & $\mathrm{~N}$ & $\mathrm{I}$ & $\mathrm{I}$ & $\mathrm{I}$ \\
\hline 2 & $\mathrm{I}$ & $\mathrm{I}$ & $\mathrm{C}$ & $\mathrm{N}$ & $\mathrm{I}$ \\
\hline 3 & $\mathrm{C}$ & $\mathrm{I}$ & $\mathrm{I}$ & $\mathrm{I}$ & $\mathrm{I}$ \\
\hline 4 & $\mathrm{I}$ & $\mathrm{I}$ & $\mathrm{I}$ & $\mathrm{I}$ & $\mathrm{N}$ \\
\hline 5 & $\mathrm{C}$ & $\mathrm{I}$ & $\mathrm{I}$ & $\mathrm{C}$ & $\mathrm{I}$ \\
\hline 6 & $\mathrm{I}$ & $\mathrm{C}$ & $\mathrm{I}$ & $\mathrm{I}$ & $\mathrm{I}$ \\
\hline 7 & $\mathrm{I}$ & $\mathrm{I}$ & $\mathrm{I}$ & $\mathrm{I}$ & $\mathrm{I}$ \\
\hline 8 & $\mathrm{I}$ & $\mathrm{N}$ & $\mathrm{I}$ & $\mathrm{I}$ & $\mathrm{I}$ \\
\hline 9 & $\mathrm{~N}$ & $\mathrm{~N}$ & $\mathrm{~N}$ & $\mathrm{~N}$ & $\mathrm{~N}$ \\
\hline 10 & $\mathrm{I}$ & $\mathrm{I}$ & $\mathrm{I}$ & $\mathrm{I}$ & $\mathrm{I}$ \\
\hline
\end{tabular}

$\mathrm{C}=$ Correct $; \mathrm{I}=$ Incorrect $; \mathrm{N}=$ Not Attempted

As shown in the table, the informants' performance was entirely unsatisfactory in this aspect of cultural competence in translation. Out of the ten informants, six provided either incorrect or no responses in all the five translation procedures tested. Meanwhile, one of the informants got two correct responses (40\%) whereas the remaining informants managed to get only one correct response $(20 \%)$. For the answer key to this part of the test, see Appendix 3.

One of the main features in the informants' performance in this part of the test is that although a few of those informants appear to be somewhat familiar with some types of translation procedures, they tend to mix them up. For example, three different labels, i.e., adaptation, calque, and cultural substitution were incorrectly identified as the translation procedures used in the rendition of the English culturespecific term Merry Christmas as عيد ميلاد سعيد / مجيد (happy / glorious birthday).

Another noticeable feature is that the ability of the informants to provide correct Arabic renditions of a few of the English CBTs tested did not correlate with their awareness of the translation procedures they used in those renditions. In other words, some informants have provided correct Arabic renditions of certain English CBTs, but they do not seem to be aware of the translation procedures they have actually used in such renditions. For example, two of the informants managed to correctly render the English CBT a three-course dinner as وجبة عشاء تتكون من ثثلاثة اطباق yet yet one of the two informants claimed that the translation procedure she used in this rendition is shift while the other labelled it as calque; neither of the two translation procedures named is correct. Meanwhile, two of the informants rendered the same English-specific expression rather imprecisely as عثاء يتكون من ثلاثنة وجبات (dinner that consists of three meals) yet they were able to correctly identify the trans- 
lation procedure, i.e., paraphrase, involved in that rendition. Likewise, another informant rendered the English culture-bound term Merry Christmas rather inappropriately as she merely transferred the term to Arabic, but she correctly spotted the translation procedure used in such rendition, i.e., transliteration.

Finally, there are a few informants who do not seem to know what a translation procedure is. This is quite evident in the rather odd labels given by those informants for the translation procedures they claimed to have used in their renditions of the CBTs tested. Examples of the labels given by those informants included common knowledge, dictionaries, and even the mind.

\section{Conclusion and recommendations}

The discussion of the students' performance in the translation test (Sections 5.1. and 5.2.) has revealed the following:

1) inadequate knowledge of some major political, religious and social aspects of the source and target cultures;

2) lack of awareness of the significance of taking the translation brief into account while translating;

3) lack of awareness of certain semantic problems in particular that of lexical gaps in a language and the manner in which such a problem would be appropriately handled in translation;

4) inadequate knowledge of the differences between the source (English) language and target (Arabic) language in the realization of certain lexical categories such as culture-specific idioms and similes;

5) inadequate knowledge of the translation procedures that are used in the rendition of culture-bound terms;

6) improper utilization of dictionaries while translating.

In the light of the findings of the present study, it would be perhaps appropriate to make the following recommendations:

1) The specific objectives and outcomes of postgraduate English-Arabic translation programmes should be set in such a manner that reflects the relative importance of cultural issues in the training of would-be translators.

2) There is a dire need for the inclusion in postgraduate English-Arabic translation programmes of a 3-credit compulsory course on culture in translation. This would be the minimum requirement for creating the right conditions to develop the students' cultural competence in translation. The proposed course should focus on the provision of sufficient knowledge of the various aspects of both source and target cultures, the promotion of the students' awareness of the differences that exist between both cultures, the development of the students' competence in rendering culture-bound terms and handling culture-laden texts in the two languages, and the enhancement of their expertise in the translation strategies and procedures used in rendering those texts and terms.

3) Greater attention should be accorded to the adequate presentation of the translation procedures that are used in the rendition of CBTs from English into Arabic. Moreover, the translator trainees should be given sufficient practice in identifying, on their own, those translation procedures in a variety of texts.

4) The integration of a variety of selected texts that deal with cultural issues in EnglishArabic translation in the translation classes as well as in the assessment of the performance of translator trainees to ensure that they study such texts carefully. 


\section{REFERENCES}

Abdel-Hafez, Ahmed-Sokarno (2004): Cultural elements in the translation of Mahdfooz's 'The Beginning and the End and Palace of Desire.' Internet Zeitschrift für Kulturwissenschaften. 15. Visited 17 February 2010, <http://www.inst.at/trans/15Nr/07_1/abdelhafiz15.htm>.

Atlas Encyclopedic Dictionary: English-Arabic (2002): Amman: Atlas Global Center for Studies and Researches.

American University of Sharjah (AUS) (2006): Graduate Degree Programs: Translation and Interpreting. Visited 17 February 2010, <http://www.aus.edu/catalog/2006/grad/grad_ Trans\&Interpr.php $>$.

AzIz, Yowell (1985): Modes of address in English-Arabic translation. Babel. 31(3):144-146.

AzIz, Yowell (1999): Cross-cultural translation and ideological shifts. International Journal of Translation. 11(1-2):29-83.

BaAlbaki, Munir (2000): Al-Mawrid: A Modern English-Arabic. Beirut: Dar El-Elm LilMalayen.

BAKer, Mona (1992): In Other Words: A Course Book on Translation. London: Routledge.

BARKHO, Leon (1987): Cultural problems of Arabic-English translation. Babel. 33(3):156-151.

CATFORD, John (1965): A Linguistic Theory of Translation. London: OUP.

Delisle, Jean, Lee-Jahnke, Hannelore and Cormier, Monique (1999): Translation Terminology. Amsterdam: John Benjamins.

FAIQ, Said (1998): Handling metaphor in sensitive texts: Contributions from Arabic-English translation. Translatio. 17(3):224-239.

Farghal, Mohammed and Borini, Ahmed (1998): Pragmalinguistic failure and the translatability of Arabic politeness formulas into English: A case study of Mahfouz's Awlad Haritna. In: Abdullah ShunnaQ, Cay Dollerup and Mohammed SARAireh, eds. Issues in Translation. Irbid: Deanship of Scientific Research, Irbid National University and Jordanian Translators' Association, 143-168.

Farghal, Mohammed and ShunnaQ, Abdullah (1999): Translation with Reference to English and Arabic: A Practical Guide. Irbid: Dar Al-Hilal for Translation.

FARRel, Mark, Rossi, Franca and Ceriani, Regina (2004): The World of English. London: Longman.

Ghazala, Hasan (2002): Cross-cultural links in translation, English-Arabic. International Journal of Translation. 14(1):137-162.

Ghazala, Hasan (2006): Translation as Problems and Solutions: A Course Book for University Students and Trainee Translators. Beirut: Dar wa Maktabat Al-Hilal.

Harvey, Malcolm (2003): A beginner's course in legal translation: The case of culture-bound terms. Visited 17 February 2010, <http://www.tradulex.org/Actes2000/harvey.pdf>.

Hatim, Basil and Mason, Ian (1990): Discourse and the Translator. New York: Longman.

Homeidi, Moheiddin (2004): Arabic translation across cultures. Babel. 50(1):13-27.

Kharma, Nayef (1997): Translation Course Book (2). Amman: Al-Quds Open University Publications.

Newmark, Peter (1988): A Textbook of Translation. New York: Prentice Hall.

NidA, Eugene (1994): Translation: possible and impossible. Turjuman. 3(2)147-163.

Nord, Christiane (1991): Text Analysis in Translation. Amsterdam: Rodopi.

SALEH, Mahmoud (2001): A Dictionary of Islamic Words and Expressions Arabic-English. Riyadh: Al-Muntada Al-Islami Publications.

ShunnaQ, Abdullah (1988): Problems in translating Arabic texts into English. In: Abdullah ShunnaQ, Cay Dollerup and Mohammmed Saraireh, eds. Issues in Translation. Irbid: Deanship of Scientific Research, Irbid National University and Jordanian Translators' Association, 33-52.

ShunnaQ, Abdullah (2000): Arabic-English translation of political speeches. Perspectives: Studies in Translatology. 8(3):207-228.

Shuttleworth, Mark and Cowie, Moira (1997): Dictionary of Translation Studies. Manchester: St. Jerome. 
SinClaIr, John, ed. (1987): Collins COBUILD English Language Dictionary. London: Collins. Snell-Hornby, Mary (1988): Translation Studies, An Integrated Approach. Amsterdam: John Benjamins.

University of Sharjah (UoS) (2006): Graduate Degree Programs: Master in English-Arabic Translation. Visited 17 February 2010, <http://www.sharjah.ac.ae/English/Academics/ Colleges/Arts_and_Sciences/Departments_and_Programs/English_Lang_Liter/Graduate/ Pages/GraduationRequirements.aspx $>$.

Vermeer, Hans (1989/2000): Skopos and commission in translational activity. In: Lawrence Venuti, ed. The Translation Studies Reader. London: Routledge, 221-232.

\section{APPENDICES}

\section{Appendix 1. Test of Cultural Competence in Translation}

Dear M.A. student:

You are requested to take this test which has been designed for research purposes only.

The aim of the test is to examine the extent to which postgraduate programmes in Arab universities have succeeded in building, in their translation trainees, proper cultural competence. You do not have to write your name.

You are allowed to use dictionaries and any other reference works as well as to search the Internet while taking the test.

There is no time limit for the test.

The question paper consists of (4) pages including this page.

Write your answers in the spaces provided on the test paper.

Attempt ALL the questions.

You are to translate the following sentences as part of a booklet, which has been written about 'British life and culture.' The booklet is assumed to have been prepared by the British Council for the purpose of providing Arab students who wish to pursue their postgraduate studies in British universities with some basic information about Britain and the British way of life.

Bearing in mind the context, purpose and readership of the target text, as defined above, give the MOST APPROPRIATE Arabic renditions of the underlined English words and expressions.

Mention the translation procedures you have used in translating the underlined words and phrases that are marked in 'bold' type.

1. The British Council has its headquarters in London.

2. A lady may be elected as 'Speaker of the House of Commons.'

3. Some restaurants offer a three-course dinner for 8 pounds.

Translation Procedure:

4. The British police sometimes go out in the streets to disperse a crowd of soccer hooligans whom you may see after a big match.

5. It may surprise you to see a punk who often has crazy hair.

Translation Procedure:

6. There are several proverbs, similes and metaphors which would be understood only if you have some knowledge about the British culture such as 'love me, love my dog,' 'as beautiful as a lark' and 'to stir one's stumps.'

Translation Procedure:

7. Many tourists come to London to visit Madame Tussauds. 
8. Halloween is on $31^{\text {st }}$ October. Children in Britain go 'trick-or-treating.'

9. You may see some Lager louts coming out of the pups late at night and smashing windows of several high-street shops.

10. During this festive season, relatives, friends and colleagues exchange cards on which the phrase 'Merry Christmas' is written.

Translation Procedure:

11. The 'poll tax,' which had been enforced by the Conservatives, was later abolished by the Labour party.

Translation Procedure:

12. Many British families take cream tea in the late afternoon.

13. British kids eat chocolates during Lent.

\section{Appendix 2. Answer Key}

1.

$$
\text { المركز الثقافي البريطاني - وهو مؤسسة تسعى لنشر اللغة الإنجليزية وتثافتها في ما وراء البحار. }
$$

(The British Cultural Center, which is an institution that seeks to spread English language and culture overseas)

2.

رئيساً لمجلس العموم البريطاني يدير جلساته ويتوجه المتحدثون بكلامهم إليه. (Speaker of the British House of Commons who chairs its sessions and to whom the speakers address their talk)

3.

وجبة عشاء تتكون من ثلاثة أجز اء، تبدأ بتتاول طبق "فاتح للثهية" كالمرق او السلطة يليه أطباق الغذاء الرئيسة وتنتهي بطبق التحلية.

(A dinner meal that consists of three parts: It starts with soup followed by the main dishes, and ends with dessert)

4.

(Riot-provoking fans of soccer clubs)

$$
\text { مشجعي أندية كرة القدم المتعصبين و المثيرين للشغب. }
$$

5.

$$
\text { . }
$$

(A punk is a person who is fond of clamorous Rock music and is distinguished by their rather unusual clothes and haircut)

$6 a$.

$$
\text { المثل الثعبي الذي يقابله في اللغة العربية بيث الشعر التالي: وأحبها وتحبني ... ويحب ناقتها بعيري. }
$$

(An English proverb to which the following Arabic line of poetry corresponds: She loves me and I love her, and my camel loves her she-camel)

$6 b$.

هذا التشبيه يستخدم عادة لوصف الصوت الغنائي لشخص ماو يعني حرفياً "جميل كطائر القبرة"، ويقابله في اللغة

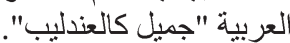

(This simile is usually used to describe a person's singing voice; it literally means 'as beautiful as a lark bird' and its equivalent Arabic simile is 'as beautiful as the nightingale.') 
6c.

هذه "استعارة" مأخوذة من لعبة (الكريكت) الإنجليزية، عندما بضرب اللاعب العيدان الثناثة الموجودة ور اء لاعبي

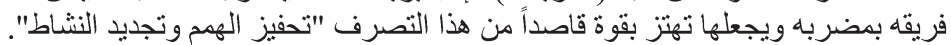

This is a 'metaphor' taken from the English cricket game: When a player hits with his bat the three posts found behind the players in his team and makes them the posts shake strongly with the intention of stimulating the players to be more active)

7.

متحف الثمع الشهير في لندن، ويتميز بوجود قو الب منحوتة بالثمع لثخصيات عالمية بارزة في مختلف المجالات من سياسيين وفنانين ورياضيبين، الخهين.

(The famous Madame Tussauds museum which is characterized by the presence of wax-carved statues of well-known international personalities from various fields - politicians, artists, sports people, etc.)

8.

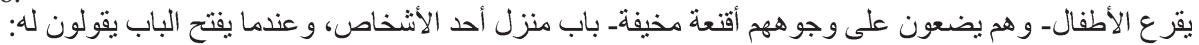

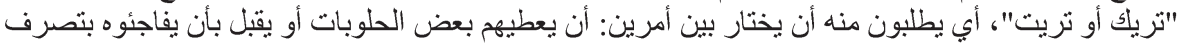

$$
\begin{aligned}
& \text { ينطوي على حيلة مخادعة. }
\end{aligned}
$$

(Children who wear terrifying masks knock on the door of the house of a person and then say to him 'trick or treat,' that is, they ask him to either give them some sweets or they play a trick on him)

9.

$$
\text { بعض التصرفان الذين الفظونة في الثوارع. اللياتية وقد انتشوا بشرب جر عات كبيرة من (البيرة) - ماركة "لاجر "- ويمارسون }
$$

(Youths coming out of night pubs after drinking large amounts of beer - Lager brand - and performing some rude acts in the streets)

10.

$$
\text { (ليكن احتفالك بعيد ميلاد المسيح سعيداً). }
$$

(Let your celebration on the occasion of the birth of Jesus Christ be happy)

11 .

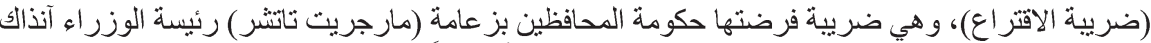

$$
\begin{aligned}
& \text { على كل مواطن له حق التصويت في الانتخابات، وأثارت جدلاً واسعاً في المجتمع البريطاني. }
\end{aligned}
$$

(The 'poll tax' is a tax imposed by the Conservative government then headed by Prime Minister Margaret Thatcher on each citizen who had the right to vote and created a huge controversy in the British society)

12.

"كريم تي"، و هي وجبة خفيفة يتناولها البريطانيون في فترة ما بعد الظهيرة وتتكون من الثابي والكيك الهش الذي

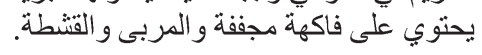

('Cream tea' is a light meal eaten by Britons in the afternoon and consists of tea and scones with dried fruit, jam and cream)

13.

$$
\text { "تناول شيء" وهي مناسبة مسيحية تمتد لفترة } 40 \text { يوم تسبق عيد الفصح، وخلال هذه الفترة يتوقف المسيحيون عادة عن . }
$$

('Lent' is a Christian occasion that extends for a period of 40 days prior to Easter, and during this period Christians often refrain from eating a particular thing such as sweets) 
Appendix 3. Translation Procedures

\begin{tabular}{|l|c|}
\hline Translation Procedures used in Appendix 2 & Test Item Number \\
\hline Paraphrase / Gloss / Explanation & 3 \\
\hline $\begin{array}{l}\text { Transcription / Borrowing / Transliteration and Paraphrase / Gloss / } \\
\text { Explanation }\end{array}$ & 5 \\
\hline Cultural equivalent & 10 \\
\hline Descriptive equivalent & 11 \\
\hline $\begin{array}{l}\text { Calque / Loan translation / Through-translation and Paraphrase / Gloss } \\
\text { / Explanation }\end{array}$ & \\
\hline
\end{tabular}

